\title{
Effects of the propagule size on the tuberous rhizome production and physicochemical characteristics of Jerusalem artichoke
}

\author{
Meiling Li ${ }^{1}$, Juan David Solano Mendoza², Lin Chau Ming² \\ ${ }^{1}$ Information Research Institute of Science and Technology, Shanghai Academy of Agricultural Sciences, Shanghai, China. E-mail: \\ lilmeilinghappy@outlook.com \\ ${ }^{2}$ Universidade Estadual Paulista, Campus de Botucatu, Botucatu, São Paulo, Brasil. E-mail: juan.solanomendoza@gmail.com, \\ linmin2809@gmail.com
}

Received: 08/01/2020; Accepted: 01/05/2020.

\begin{abstract}
As a crop that is rich in oligosaccharides, Jerusalem artichoke is considered one of the most promising plants for production because of its ability to survive in marginal lands, strong resistance to biotic and abiotic stresses, ease of conversion into biofuels, and use for food consumption. In the present study, the effects of propagule size on tuberous rhizome production and the physicochemical characteristics of Jerusalem artichoke were evaluated. Five propagule sizes of tuberous rhizome, $10 \mathrm{~g}$ (T1), $30 \mathrm{~g}$ (T2), $50 \mathrm{~g}$ (T3), $70 \mathrm{~g}$ (T4), and $90 \mathrm{~g}$ (T5), were used in a completely randomized experiment with 5 replicates and 11 plants per replicate. Harvesting was carried out 164 days after planting. The results showed that $\mathrm{T} 1$ resulted in the lowest emergence rate, number of tuberous rhizomes and aboveground fresh weight per plant of all the treatments. However, there was no significant difference among treatments in the tuberous rhizome dry weight, $\mathrm{pH}$, titratable acidity, Brix, or reducing sugar. Propagule with tuberous rhizome of 30-50 $\mathrm{g}$ is recommended to achieve a high emergence rate and yield.
\end{abstract}

Keywords: Helianthus tuberosus L., tuberous rhizomes, physicochemical characteristics, underground biomass.

\section{Tamanho de propágulos de alcachofra-de-jerusalém (Helianthus tuberosus L.) na produção e características físico-químicas de seus rizomas}

\section{RESUMO}

A alcachofra-de-jerusalém, rica em oligossacarídeo, é considerada uma das plantas mais promissoras, porque é cultivável em terras marginais, possui alto rendimento de biomassa, forte resistência a estresses bióticos e abióticos, é fácil de se converter em biocombustíveis, além de ser uma opção alimentar. No presente estudo, avaliou-se o efeito do tamanho de propágulos no crescimento, rendimento e características físico-químicas de alcachofra-dejerusalém. Utilizaram-se cinco tamanhos de propágulos: $10 \mathrm{~g}$ (T1), 30 g (T2), 50 g (T3), 70 g (T4) e 90 g (T5), em experimento em delineamento inteiramente casualizado, com 5 repetições e 11 plantas por repetição. A colheita foi realizada 164 dias após o plantio. Verificou-se que o T1 apresentou menor taxa de emergência, massa fresca total do rizoma (MFTR) e da parte aérea (MFTPA), em comparação aos demais tratamentos. Não houve diferença significativa na massa seca total do rizoma (MSTR), $\mathrm{pH}$, acidez titulável, Brix, e açúcar redutor (AR) entre os tratamentos, enquanto T1 apresentou levemente menor teor total de açúcar (AT) e sacarose. Recomenda-se a propagação às plantas a partir de rizomas tuberosos com massa de 30 até $50 \mathrm{~g}$ para se obter maior taxa de emergência e rendimento.

Palavras-chave: Helianthus tuberosus L, rizomas tuberosos, características físico-químicas, biomassa subterrânea. 


\section{Introduction}

Jerusalem artichoke (Helianthus tuberosus L.) is a perennial plant that originated in North America and belongs to the Asteraceae family (Brezeanu et al., 2016). The uses of its tuberous rhizomes are diverse, and they can be used for human and animal consumption or industrial purposes. They can be used in the manufacturing of flour, fructose syrup, and inulin (Kays and Nottingham, 2008), in the development of probiotic products (Rocha et al., 2006) and silage (Razmkhah et al., 2017), and as a biomass source for the production of fuel alcohol (Johansson et al., 2015).

The phenotypic variation is very high between different varieties of Jerusalem artichoke. The color of the tuberous rhizomes ranges from yellow to red (Goetz, 2011), and their length, size, and weight differ with their varied adaptability to distinct environments (Diederichsen, 2010). According to Izsáki and Kádi (2013), the Jerusalem artichoke yield can vary from 15 to $28 \mathrm{t} \mathrm{ha}^{-1}$ depending on the variety.

The growth, yield of tuberous rhizomes and chemical composition of Jerusalem artichoke are influenced by ecological conditions, varietal characteristics, and cultivation technology (Izsáki and Kádi, 2013). Generally, Jerusalem artichoke is propagated using all or part of its tuberous rhizomes. (Alla et al., 2014), and its size and shape are attributed to its critical quality and strongly related to its final yield (Brezeanu et al., 2016).

Previous results showed that the propagule size of Jerusalem artichoke tuberous rhizomes is important for its growth and propagules that are less than $40 \mathrm{~g}$ exhibit a reduced emergence rate (Delbetz, 1867; Morrenhof and Bus, 1990), the number of stems (Boswell et al., 1936), and the production (Boswell, 1959; Kovac et al., 1983). According to Kays and Nottingham (2008), Jerusalem artichoke is propagated from its tuberous rhizomes weighing from 45 to $60 \mathrm{~g}$ (Baillargé, 1942; Kays and Nottingham, 2008). Li et al. (2005) demonstrated that the main stem and photosynthetic area increased with the increasing propagule size of Jerusalem artichoke tuberous rhizomes, but the increases were not outweighed by the enhanced consumption of propagule.

Although Jerusalem artichoke can be found growing in the wild in many parts of the world due to its high adaptability to diverse environments, agronomic practices for its production have been poorly investigated (Rossini et al., 2019; Kays and Nottingham, 2008; Barloy et al., 1988). Some studies have described the effects of the propagule size on the growth and yield of Jerusalem artichoke; however, they focused only on the botanical characteristics (Alla et al., 2014; Lloret et al., 1999; Seiwa, 2000), and the effects of the propagule size on its chemical composition are rarely mentioned.

In light of the above observations, there is limited information available about the effect of propagule size of tuberous rhizome on the morphological and physiological characteristics of Jerusalem artichoke. Therefore, the aim of the study was to investigate the response of Jerusalem artichoke growth, yield, and physicochemical characteristics to the propagule size of its tuberous rhizome.

\section{Material and Methods}

In the current study, tuberous rhizomes of Jerusalem artichoke from the collection of medicinal plants in the Department of Horticulture, Agronomical Sciences College, São Paulo State University (UNESP), Campus of Botucatu (22 $2^{\circ} 1^{\prime} \mathrm{S}$; $\left.48^{\circ} 27^{\prime} \mathrm{W}\right)$, São Paulo, Brazil, were used. The experiment was conducted from October 24, 2015, to April 8, 2016, in a greenhouse with shade net (with 50\% shade). The climate is defined as CWa according to the Köppen-Geiger climate classification system (Alvares et al., 2013).

To plant the tuberous rhizomes, $5 \mathrm{~L}$ plastic containers (polyethylene) containing a substrate composed of $75 \%$ soil (sandy clay loam soil) and $25 \%$ substrate were used. The substrate characteristics were $60 \%$ moisture, $130 \%$ water retention capacity, $200 \mathrm{~kg} / \mathrm{m}^{3}$ density, $5.8 \mathrm{pH}$ and $2.0 \mathrm{mS} / \mathrm{cm}$ electrical conductivity. The distance between plants was $0.40 \mathrm{~m}$, and the distance between lines was $0.80 \mathrm{~m}$. The soil was collected from the $0-20 \mathrm{~cm}$ soil layer of a field where no crop production or agricultural practices had occurred in the last 10 years. After collection, the soil sample was air-dried and sieved through a $2 \mathrm{~mm}$ sieve for soil fertility analyses (Table 1 ). The $\mathrm{pH}\left(\mathrm{CaCl}_{2}\right)$, organic matter $(\mathrm{O} . \mathrm{M}), \mathrm{P}_{\text {resin }}, \mathrm{H}+\mathrm{Al}, \mathrm{K}$, $\mathrm{Ca}$ and $\mathrm{Mg}, \mathrm{SB}$ (sum of bases), CEC (cation exchange capacity) and BS (base saturation, \%) were determined according to the methodology described by Raij et al. (2001).

The experimental design used was randomized blocks with five treatments and five repetitions per treatment. The treatments were tuberous rhizome propagule sizes of $10 \mathrm{~g}, 30 \mathrm{~g}, 50 \mathrm{~g}, 70 \mathrm{~g}$, and $90 \mathrm{~g}$. Each plot contained 11 useful plants, for 220 plants in total. Manual irrigation was performed daily, and the amount of water applied was up to the maximum capacity of the field soil.

Table 1. Chemical properties of the soil used in the experiment.

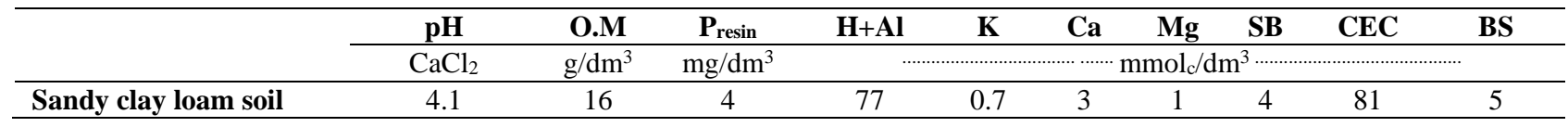


The emergence rate was calculated by the proportion of the number of germinated plants to the total number of plants planted. Plant height was measured from December 8, 2016 (two weeks after emergence) and was measured from the base of the plant to the apex every 30 days with a measuring tape.

The tuberous rhizomes were harvested at 164 days after planting. Subsequently, they were taken to the postharvest laboratory for cleaning and weighing. The data are expressed in grams of fresh weight per plant. For the determination of tuberous rhizome dry matter, a sample of $100 \mathrm{~g}$ of tuberous rhizomes was removed, thinly sliced and placed in an oven with air circulation at $65^{\circ} \mathrm{C}$ until mass stabilization, which occurred at $48 \mathrm{~h}$.

The tuberous rhizomes were stored in a cold chamber at $5 \pm 1{ }^{\circ} \mathrm{C}$ with relative humidity $90 \pm 5 \%$ for a period of three days. After this period, the tuberous rhizomes were shredded in a food processor and placed in $50 \mathrm{~mL}$ plastic pots for the analyses of soluble solids, $\mathrm{pH}$, reducing sugars, and total sugars.

Soluble solids were determined by the refraction index measure, according to the methodology recommended by AOAC (2005). The reading was performed with a digital refractometer (Atago Co., LTDA, Japan), and the results were expressed in degrees Brix. The $\mathrm{pH}$ was measured using the aqueous extract in a model B-221 micronal potentiometer according to the methodology recommended by the Adolfo Lutz Institute (1985). The total reducing sugar content was determined according to the methodology described by Somogyi, adapted by Nelson (1944). The reading was done in a Micronal B382 spectrophotometer at $535 \mathrm{~nm}$. The results for the reducing sugars and total sugars were expressed in $\%$.

The nonreducing sugar content, expressed as the sucrose content, was determined by the difference in the total sugar content and the reducing sugar content. The results were then multiplied by 0.95 and expressed as \% (Cecchi, 2003).

The data were submitted to variance analysis in addition to a Tukey test. $\mathrm{P}<0.05$ was considered significant. The software used was SAS 9.4. The graphs were made by Sigmaplot ${ }^{\circledR}$ (Version 11.0, ISI, USA).

\section{Results and Discussion}

\subsection{Emergence rate and plant height}

It was observed that $\mathrm{T} 5$ resulted in the highest emergence rate (e.g., $64.85 \%$ on average), and $\mathrm{T} 1$ had the lowest value (e.g., $7.56 \%$ on average) compared to the other treatments (Figure 1). It can be seen that the smaller propagule of tuberous rhizome had a negative impact on the emergence rate. This conclusion is supported by previous studies; for example, Boswell et al. (1936) assessed the effect of the propagule size of Jerusalem artichoke and obtained significantly lower values for the emergence rate (\%) at propagule smaller than $28.35 \mathrm{~g} \mathrm{(1}$ ounce). A similar result was obtained by Delbetz (1867), who found that propagule of tuberous rhizome smaller than $40 \mathrm{~g}$ resulted in lower emergence rates for Jerusalem artichoke. This result is also in accordance with the reports of Slivertown (1981) and Seiwa (2000), who demonstrated that the emergence rate of Jerusalem artichoke was negatively influenced by smaller propagule of tuberous rhizome.

There was no significant difference among the different propagule sizes of tuberous rhizome for plant height. T1 $(68.89 \mathrm{~cm})$ and T2 $(79.94 \mathrm{~cm})$ resulted in slightly shorter plants than T3 $(84.34 \mathrm{~cm}), \mathrm{T} 4(83.15 \mathrm{~cm})$, and T5 $(86.70 \mathrm{~cm})$. This result was consistent with Shen et al. (2019), who found that a propagule lower than 6.5 g significantly restrained potato growth, while little difference was observed in plant height between propagules of $12.5 \mathrm{~g}$ and $25 \mathrm{~g}$. The results in this work showed that the plant height of T1 increased sharply and tended to be the highest at 104 days after planting; however, it decreased faster than those in the other treatments. This indicates that using a smaller tuberous rhizome for propagation can negatively affect the growth of Jerusalem artichoke.

Figure 1. Emergence rate and plant height of Jerusalem artichoke at different propagule sizes of tuberous rhizome. Botucatu, 2015-2016.
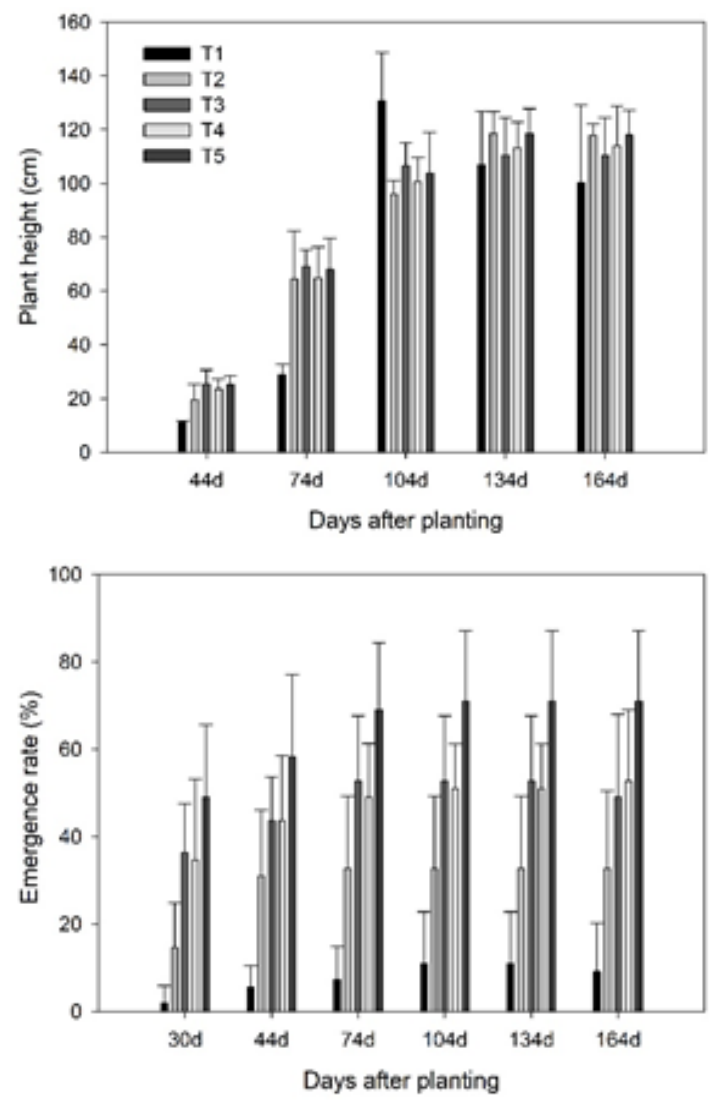

Note: T1, T2, T3, T4, and T5 represent five propagule sizes: 10 $\mathrm{g}, 30 \mathrm{~g}, 50 \mathrm{~g}, 70 \mathrm{~g}$, and $90 \mathrm{~g}$, respectively. 


\subsection{Production of tuber rhizomes}

The agronomic characteristics of the tuberous rhizomes, such as mass and shape, are critical quality attributes and are strongly related to the final yield (Brezeanu et al., 2016). Previous studies have shown that large propagule of tuberous rhizome result in rapid germination and a high emergence rate, which in the end promote yield accumulation (Lloret et al., 1999; Seiwa, 2000).

It was found that the aboveground fresh weight (AGFW) and tuberous rhizome fresh weight per plant (TRFW) were influenced significantly by the size of the Jerusalem artichoke propagule (Table 2), while there was no significant difference between the treatments for tuberous rhizome dry weight (TRDW) or its dry matter in percentage (TRDMP), which varied from $21,6 \%$ to 24,0\%. T1 resulted in the lowest AGFW (47.4 g per plant) and TRFW values (104.7 g per plant) of all the treatments, while there were no significant differences among T2, T3, T4, and T5. Variance analysis showed that the AGFW and TRFW were $84 \%$ and $62 \%$ higher (on average), respectively, in the other treatments than in T1.

These values are similar to the results observed by Kovac et al. (1983) and Kays and Nottingham (2008), who reported an increased accumulation of tuberous rhizomes with propagules greater than $40 \mathrm{~g}$. The result of the current study was consistent with the study of Boswell et al. (1936), who investigated the effects of four propagule sizes of tuberous rhizome $(7 \mathrm{~g}, 14 \mathrm{~g}, 28 \mathrm{~g}$, and $56 \mathrm{~g}$ ) on Jerusalem artichoke yield and reported that the propagules should be at least $28 \mathrm{~g}$ in weight, preferably $56 \mathrm{~g}$. Shen et al. (2019) also found that a large propagule size ( $>25 \mathrm{~g}$ ) is more favorable to high tuberous rhizome yield and aboveground weight in potato. In summary, for the purpose of guaranteeing yield, propagules of tuberous rhizome ranging from 20 to $30 \mathrm{~g}$ are favorable to the survival of rhizome seedlings and result in greater economic benefits than smaller propagules.

\subsection{Physicochemical analysis}

The propagules size of tuberous rhizome had no significant effect on the $\mathrm{pH}$, titulavel acidity, Brix, reducing sugar (RS) or total sugar (TS) of Jerusalem artichoke (Table 3). One of the most important quality parameters of Jerusalem artichoke is the total sugar content, which represents up to approximately $80 \%$ of the dry mass of the tuberous rhizome, and the main carbohydrate is inulin (Terzić and Atlagić, 2009; Filipović o et al., 2016). In this study, TS varied from 10,77 to $13,0 \%$ and represented between 40 and $50 \%$ of tuberous rhizome dry matter (Table 3 ). These results were similar to those observed by Rakhimov et al. (2011), who determined the total sugar content and observed that its average value was $13.4 \%$.

In the present study, the sucrose content varied from 9.0 to $11.8 \%$ and represented 80 to $90 \%$ of the total sugar content (Table 3 ). The sucrose content was found to vary according to the propagule sizes of tuberous rhizome. The statistical analyses showed that the sucrose content in T1 and T2 was slightly lower than that in the other treatments. Sucrose is one of the main forms of plant sugar storage, accumulation, and transport, and there is limited information on the sucrose content of Jerusalem artichoke grown from different propagule sizes. However, the results achieved in this work showed that the propagules size influenced photosynthesis accumulation and the growth of the tuberous rhizomes.

Table 2. Production of Jerusalem artichoke tuberous rhizomes with different propagule sizes of tuberous rhizome. Botucatu, 2016.

\begin{tabular}{ccccc}
\hline Treatments & AGFW $(\mathrm{g} / \mathrm{p})$ & TRFW $(\mathrm{g} / \mathrm{p})$ & TRDW $(\mathrm{g} / \mathrm{p})$ & TRDMP $(\%)$ \\
\hline T1 & $47.7 \mathrm{~b}$ & $104.7 \mathrm{~b}$ & $23.1 \mathrm{a}$ & $23.1 \mathrm{a}$ \\
T2 & $89.0 \mathrm{a}$ & $163.3 \mathrm{a}$ & $21.6 \mathrm{a}$ & $21.6 \mathrm{a}$ \\
T3 & $87.5 \mathrm{a}$ & $150.2 \mathrm{ab}$ & $23.6 \mathrm{a}$ & $23.6 \mathrm{a}$ \\
T4 & $77.3 \mathrm{a}$ & $191.4 \mathrm{a}$ & $22.4 \mathrm{a}$ & $22.4 \mathrm{a}$ \\
T5 & $97.7 \mathrm{a}$ & $173.4 \mathrm{a}$ & $24.0 \mathrm{a}$ & $24.0 \mathrm{a}$ \\
CV & 21.74 & 22.05 & 15.79 & 25.44 \\
LSD & 23.26 & 46.30 & 4.85 & 5.47 \\
\hline
\end{tabular}

Note: AGFW: aboveground fresh weight per plant; TRFW: tuberous rhizome fresh weight per plant; TRDW: tuberous rhizome dry weight; TRDMP: tuberous rhizome dry matter as a percentage. T1, T2, T3, T4, and T5 represent the five propagule sizes of tuberous rhizome: $10 \mathrm{~g}, 30 \mathrm{~g}, 50 \mathrm{~g}, 70 \mathrm{~g}$, and $90 \mathrm{~g}$, respectively.

Table 3. Physicochemical properties of rhizomes of Jerusalem artichoke grown from different propagule sizes of tuberous rhizome. Botucatu, 2016.

\begin{tabular}{ccccccc}
\hline Treatments & $\mathrm{pH}$ & Titulavel acidity $(10 \mathrm{~g})$ & ${ }^{\circ}$ Brix & RS $(\%)$ & TS $(\%)$ & Sucrose $(\%)$ \\
\hline T1 & $6.8 \mathrm{a}$ & $2.2 \mathrm{a}$ & $13.9 \mathrm{a}$ & $0.7 \mathrm{ab}$ & $11.2 \mathrm{ab}$ & $9.0 \mathrm{~b}$ \\
T2 & $6.5 \mathrm{ab}$ & $2.4 \mathrm{a}$ & $12.8 \mathrm{a}$ & $0.8 \mathrm{a}$ & $11.3 \mathrm{ab}$ & $9.9 \mathrm{~b}$ \\
$\mathrm{~T} 3$ & $6.6 \mathrm{ab}$ & $2.2 \mathrm{a}$ & $13.7 \mathrm{a}$ & $0.8 \mathrm{a}$ & $12.4 \mathrm{ab}$ & $10.7 \mathrm{ab}$ \\
$\mathrm{T} 4$ & $6.6 \mathrm{ab}$ & $2.0 \mathrm{a}$ & $12.4 \mathrm{a}$ & $0.8 \mathrm{a}$ & $11.9 \mathrm{ab}$ & $10.6 \mathrm{ab}$ \\
T5 & $6.5 \mathrm{ab}$ & $2.0 \mathrm{a}$ & $14.0 \mathrm{a}$ & $0.6 \mathrm{ab}$ & $13.0 \mathrm{a}$ & $11.8 \mathrm{a}$ \\
CV & 2.05 & 14.93 & 8.87 & 16.20 & 10.77 & 12.39 \\
LSD & 0.182 & 0.43 & 1.59 & 1.6 & 1.73 & 1.73 \\
\hline
\end{tabular}

Note: RS-Reducing sugar; TS-Total sugar. T1, T2, T3, T4, and T5 represent the five propagule sizes of tuberous rhizome: $10 \mathrm{~g}, 30 \mathrm{~g}$, $50 \mathrm{~g}, 70 \mathrm{~g}$, and $90 \mathrm{~g}$, respectively. 


\section{Conclusions}

The propagule size of tuberous rhizome has an influence on underground production, the number of seedlings germinated, and the plant height of Jerusalem artichoke. Lower biomass values were recorded for smaller propagule of tuberous rhizomes. Additionally, the propagule size of tuberous rhizome had no significant effect on physicochemical characteristics, such as $\mathrm{pH}$, titratable acidity, Brix, reducing sugar, and total sugars, while the sucrose content was greater at propagule of 50 $\mathrm{g}, 70 \mathrm{~g}$, and $90 \mathrm{~g}$ than at $10 \mathrm{~g}$ and $30 \mathrm{~g}$. According to the results obtained in this work, propagule size of tuberous rhizomes ranging from $30 \mathrm{~g}$ to $50 \mathrm{~g}$ is recommended for the cultivation of Jerusalem artichoke.

\section{Bibliographic References}

Alla, N.A., Domokos-Szabolcsy, É., El-Ramady, H., Hodossi, S., Fári, M., Ragab, M., Taha, H., 2014. Jerusalem artichoke (Helianthus tuberosus L.): A review of in vivo and in vitro propagation. International Journal of Horticultural Science, 20 (3-4), 131-136.

Alvares, C.A., Stape, J.L., Sentelhas, P.C., Gonçalves, J.L.M., Sparovek, G., 2013. Köppen's climate classification map for Brazil. Meteorologische Zeitschrift, 22(6), 711-728.

AOAC. Association of official agricultural chemistry, 2005. Official Methods of Analysis. Washington, DC, 598 p.

Baillargé, E., 1942. Le topinambour. Flamnarion, Paris.

Barloy, J., 1988. Identification Criteria for Jerusalem Artichoke Clones, in: Grassi, G., Gosse, G., (Eds). Topinambur (Jerusalem artichoke). Report No. EUR 11855 EN-FR-IT of the EEC; Elsevier: Amsterdam, The Netherlands, p. 125-136.

Boswell, V.R., 1959. Growing the Jerusalem artichoke. USDA, Washington, DC (Leaflet No. 116).

Boswell, V.R., Steinbauer, C.E., Babb, M.F., Burlison, W.L., Alderman, W.H., Schoth, H.A., 1936. Studies of the culture and certain varieties of the Jerusalem artichoke. USDA, Washington, DC, p. 1-70 (Technical Bulletin No. 514).

Brezeanu, P.M., Brezeanu, C., Ambarus S., Robu, T., 2016. Preliminary study on agronomic performance of Jerusalem artichoke species. Journal of Horticulture, Forestry and Biotechnology, 20(3), 132-136.

Cecchi, H.M., 2003. Fundamentos teóricos e práticos em análise de alimentos, segunda ed. Campinas, Unicamp.

Delbetz, P.T., 1867. Du Topinambour: Culture, Panification et Distillation de ce Tubercule. Libraire Centrale d'Agriculture et de Jardinage, Paris, 174 p.

Diederichsen, A., 2010. Phenotypic diversity of Jerusalem artichoke Helianthus tuberosus L. Gerrmplasm preserved by the Canadiam Genebank. Helia, 33(53), 1-16.
Filipović, V., Radanović, D., Marković, T., Ugrenović, V., Protić, R., Popović, V., Sikora, V., 2016. Productivity and tuber quality of Helianthus Tuberosus L. cultivated on different soil types in Serbia. Romanian Biotechnological Letters, 21(4), 11695-11704.

Goetz, P., 2011. Helianthus tuberosus - Topinambour. Phytothérapie, 9(2), 117-119.

Instituto Adolfo Lutz, 1985. Normas analíticas do Instituto Adolfo Lutz: métodos químicos e físicos para análise de alimentos, terceira ed. IMESP, São Paulo.

Izsáki, Z., Kádi, G.N., 2013. Biomass accumulation and nutrient uptake of Jerusalem Artichoke (Helianthus tuberosus L.). American Journal of Plant Sciences, 4(8), 1629-1640.

Johansson, E., Prade, T., Angelidaki, I., Svensson, S.E., Newson, W.R., Gunnarsson, I.B., Hovmalm, H.P., 2015. Economically viable components from Jerusalem artichoke (Helianthus tuberosus $\mathrm{L}$ ) in a biorefinery concept. International Journal of Molecular Sciences, 16(4), 8997-9016.

Kays, S.J., Nottingham, S.F., 2008. Biology and Chemistry of Jerusalem Artichoke: Helianthus tuberosus L. CRC Press, Taylor and Francis Group, Boca Raton.

Kovac, V., Pekic, B., Berenji, J., 1983. Jerusalem artichoke as a potential raw material for the production of alcohol, in microbiological conversion of raw materials and by-products of agriculture into proteins, alcohol, and other products. Seminar Proceedings, Novi Sad, Yugoslavia, p. 35-51.

Li, L., Zhong, Q.W., Ma, B.Y., Hou, Q., Li, J., 2005. Effect of propagation weight on yield of Jerusalem artichoke No.1. Qinghai Science and Technology, (6), 17-19.

Lloret, F., Casanovas, C., Penuelas, J., 1999. Seedling survival of Mediterranean shrubland species in relation to root: shoot ratio seed size and water and nitrogen use. Functional Ecology, 13(2), 210-216.

Morrenhof, H., Bus, C.B., 1990. Aardper, een potentieel nieuw gewas-teeltonderzoek 1986-1989, in: Verslag No. 99, Research Station for Arable Farming and Field Production of Vegetables (PAGV), Lelystad, 66 p.

Nelson, N.A., 1944. Photometria adaptation of Somogyi method for determination of glicose. Journal Biological Chemistry, 31(2), 159-161.

Raij, B., Andrade, J.C., Cantarella, H., Quaggio, J.A., 2001. Chemical analysis for fertility evaluation of tropical soils. IAC, Campinas.

Rakhimov, D.A., Zhauynbaeva, K.S., Mezhlumyan, L.G., Syrov, V.N., Khushbaktova, Z.A., Salikhov, S.A., Mavlyanova, R.F., 2011. Carbohydrate and protein components of Helianthus tuberosus and their biological activity. Chemistry of Natural Compounds, 47(4), 503-506.

Razmkhah, M., Rezaei, J., Fazaeli, H., 2017. Use of Jerusalem artichoke tops silage to replace corn silage in sheep diet. Animal Feed Science and Technology, 228, 168-177.

Rocha, J.R., Catana, R., Ferreira, B.S., Cabral, J.M.S., Fernandes, P., 2006. Desing and characterization of an enzyme system for inulin hydrolysis. Food Chemistry, 95(1), 77-82. 
Rossini, F., Provenzano, M.E., Kuzmanović, L., Ruggeri, R., 2019. Jerusalem Artichoke (Helianthus tuberosus L.): a versatile and sustainable crop for renewable energy production in Europe. Agronomy, 9(9), 1-22.

Seiwa, K., 2000. Effects of seed size and emergence time on tree seedling establishment: importance of developmental constraints. Oecologia, 123(2), 208-215.

Shen, S.F., Wu, L.H., Xiang, C., Li, B., 2019. Effects of seed size and pot culture on potato growth and yield in autumn. Seed, 38(6), 88-90.
Slivertown, J.W., 1981. Seed size life span and germination date as co-adapted features of plant life history. American Naturalist, 118(6), 860-864.

Terzić, S., Atlagić, J., 2009. Nitrogen and sugar content variability in tubers of Jerusalem artichoke (Helianthus tuberosus). Genetika, 41(3), 289-295. 